\title{
TOLERANSI DALAM UMAT BERAGAMA DALAM MEMPERKOKOH PERSATUAN DAN KESATUAN BANGSA DI DUSUN SEGARAN KECAMATAN DLANGGU KABUPATEN MOJOKERTO
}

\author{
Whindy Salsa Nabila \\ IIK STRADA INDONESIA \\ whindysalsanabila@gmail.com
}

\begin{abstract}
Abstrak
Bangsa Indonesia dikenal sebagai bangsa majemuk, ditandai dengan banyaknya etnis, suku, agama, budaya, kebiasaan, di dalamnya. Di sisi lain, masyarakat Indonesia dikenal sebagai masyarakat multikultural, masyarakat yang anggotanya memiliki latar belakang budaya beragam. Sebaliknya, bila tidak dikelola secara benar, kemajemukan dan multikulturalitas bisa menimbulkan bencana dahsyat. Nation and character building sebagai cita-cita membentuk kebudayaan nasional sebagai wahana pemersatu bangsa cenderung belum terwujud. Malah akhir-akhir ini semangat yang menjurus pada kesukubangsaan semakin bertambah besar sepertinya semangat mengutamakan paham suku-bangsa lebih beradab dan maju ketimbang suku-bangsa yang lainnya cenderung tumbuh. Pedoman kehidupan berbangsa dan bernegara yang sarat dengan itikad menjaga, melindungi, mempersatukan dan membangun bangsa untuk mampu meraih kemajuan adab, setara dengan bangsa bangsa maju lainnya di dunia seolah-olah menjadi barang usang yang sudah ditinggalkan.
\end{abstract}

\section{Kata Kunci: Persatuan dan Kesatuan Indonesia}

\section{LATAR BELAKANG}

Bangsa Indonesia dikenal sebagai bangsa yang majemuk, ditandai dengan banyaknya etnis, suku, agama, bahasa, budaya, dan adat-istiadat. Untuk persoalan agama, negara Indonesia bukanlah sebuah negara teokrasi, melainkan secara konstitusional negara mewajibkan warganya untuk memeluk satu dari agama-agama yang diakui eksistensinya sebagaimana tercantum di dalam pasal 29 ayat dan UUD 1945. Negara memberi kebebasan kepada penduduk untuk memilih salah satu agama yang telah ada di Indonesia yaitu agama Islam, Kristen Protestan, Kristen Katolik, Hindu, Budha dan Konghuchu. Pengembangan agama dan kehidupan beragama tidak boleh menjurus ke arah tumbuhnya pemikiran dan pemahaman agama yang sempit karena hal ini akan menimbulkan konflik antar agama. Sebagaimana yang diungkapkan oleh Abdul Kadir mengenai potensi integrasi akan terjadi apabila terdapat suasana keharmonisan hubungan dalam dinamika pergaulan terutama intern umat beragama dan antar umat beragama. Sebaliknya, potensi disintegrasi akan menjadi kenyataan apabila terdapat suasana saling curiga dan persaingan dalam dinamika baik intern umat beragama maupun antar umat beragama. Setiap perwujudan mengandung ciri-ciri tertentu yang membedakannya dari perwujudan yang lain. Tidak mungkin pula apabila semua perwujudan itu sama karena menunjukkan tidak akan ada perkembangan atau 
kemajuan pada suatu bangsa. Atas dasar pemahaman tersebut, perbedaan-perbedaan yang ada dalam kehidupan masyarakat Indonesia sebenarnya untuk memenuhi kepentingan bersama agar dapat hidup sejahtera. Dalam kehidupan masyarakat yang serba majemuk, berbagai perbedaan yang ada seperti dalam suku, agama, ras atau antar golongan, merupakan realita yang harus didayagunakan untuk memajukan negara dan bangsa Indonesia, menuju cita-cita yang diinginkan yaitu masyarakat adil dan makmur berdasarkan Pancasila dan UUD 1945 dalam Negara Kesatuan Republik Indonesia.

Menurut Webster's New American Dictionary arti tolerance adalah liberty toward the opinions of others, patience with others yang kalau diterjemahkan ke dalam Bahasa Indonesia artinya adalah memberi kebebasan pendapat orang lain, dan berlaku sabar menghadapi orang lain. Jadi toleransi adalah sikap lapang dada terhadap prinsip orang lain, tidak berarti seseorang harus mengorbankan kepercayaan atau prinsip yang dianutnya melainkan harus tercermin sikap yang kuat atau istiqamah untuk memegangi keyakinan atau pendapat sendirinya.

Dengan adanya toleransi maka akan dapat melestarikan persatuan dan kesatuan bangsa, mendukung dan menyukseskan pembangunan, serta menghilangkan kesenjangan. Toleransi agama adalah toleransi yang menyangkut keyakinan yang berhubungan dengan akidah yaitu sikap lapang dada untuk memberi kesempatan pemeluk agama selain Islam beribadah menurut ketentuan agama yang diyakininya. Sedangkan, toleransi sosial berorientasi terhadap toleransi kemasyarakatan. Dalam masyarakat yang beragam karena perbedaan agama dianjurkan untuk menegakkan kedamaian dan melakukan kerjasama dengan orang-orang yang berlainan agama dalam batas batas yang telah di tentukan. Negara berperan sebagai penata kehidupan nasional yang harmonis di atas pluralitas agama-agama yang ada, sementara tokoh agama berperan sebagai penyiar ajaran yang bijak dan sinergis sehingga misi agama sebagai pencipta perdamaian dapat terasa bagi kehidupan bernegara khususnya dalam hal memperkokoh persatuan dan kesatuan bangsa. Citra positif agama melalui perilaku umat beragama yang toleran dan bijak akan turut menentukan terhadap citra positif negara. Persatuan dan kesatuan bangsa merupakan suatu kondisi dan cara terbaik untuk mencapai tujuan bersama. Suatu masyarakat yang didorong oleh keharusan memenuhi kebutuhannya perlu bekerja sama atau bersatu.

Untuk tetap menjaga persatuan dan kesatuan bangsa Indonesia maka diperlukan kesadaran individu dan kesadaran kolektif sebagai wujud kesetiaan kepada negara. Secara individual harus memiliki kesadaran bahwa ada perbedaan di antara kehidupan manusia. Kesadaran perbedaan ini kemudian diteruskan melalui dialog dan interaksi sosial untuk dapat saling memberi dan saling menerima dalam kesetaraan. Melalui kesadaran individual juga mencoba mencari dan merumuskan kesepakatankesepakatan sosial tanpa harus kehilangan jati diri dan karakteristik masingmasing. Inilah wujud dari sikap toleransi yang saling menghormati dan menghargai dalam perbedaan. Sedangkan, kesadaran kolektif memandang konflik sosial merupakan hasil dari perbedaan kepentingan sosial, ekonomi dan politik yang berdampak adanya pelanggaran terhadap hak-hak sekelompok orang oleh kelompok orang yang lainnya. 
Masyarakat Dusun Segaran Kecamatan Dlanggu Kabupaten Mojokerto memiliki penduduk yang heterogen khususnya dalam hal agama. Berdasarkan data demografi Dusun Segaran Kecamatan Dlanggu Kabupaten Mojokerto, persentase antara penduduk yang memeluk agama Islam dengan penduduk yang beragama Kristen adalah $70 \%$ : 30\%. Jumlah keseluruhan masyarakat Dusun Segaran Kecamatan Dlanggu Kabupaten Mojokerto ada 987 jiwa, dengan jumlah laki-laki 491 jiwa dan perempuan ada 496 jiwa. Dari jumlah keseluruhan masyarakat Dusun Segaran ada 690 jiwa yang memeluk agama islam dan 297 jiwa yang memeluk agama kristen. Berdasarkan proses difusi yaitu penyebaran unsur-unsur kebudayaan ke seluruh penjuru dunia. Salah satu bentuk difusi adalah penyebaran unsur-unsur kebudayaan dari satu tempat ke tempat lain di muka bumi, yang dibawa oleh kelompokkelompok manusia yang bermigrasi. Bentuk difusi yang lain berdasarkan pertemuan-pertemuan antara individu-individu dalam suatu kelompok manusia dengan individu-individu kelompok tetangga. Pertemuan ini dapat berlangsung dengan berbagai cara. Salah satunya yaitu karena perdagangan. Persebaran dari individu satu ke individu lain, dan dari masyarakat satu ke masyarakat yang lain akan memperkaya kebudayaan di suatu masyarakat. Saat kebudayaan Islam masuk di tengah-tengah kebudayaan Kristen maka akan terjadi proses difusi karena secara tidak langsung akan turut mempengaruhi kebudayaan awal yang ada di dusun tersebut.

\section{RUMUSAN MASALAH}

a. Apa pengertian persatuan dan kesatuan bangsa?

b. Bagaimana makna dan pentingnya persatuan dan kesatuan bangsa?

c. Bagaimana cara mewujudkan persatuan dan kesatuan bangsa?

d. Nilai-nilai dasar yang menjadi landasan terbentuknya toleransi antar umat beragama Islam dan Keristen di dusun Segaran kecamatan Dianggu kabupaten Mojokerto

\section{TINJAUAN PUSTAKA}

Bangsa Indonesia dikenal sebagai bangsa majemuk, ditandai dengan banyaknya etnis, suku, agama, budaya, kebiasaan, di dalamnya. Di sisi lain, masyarakat Indonesia dikenal sebagai masyarakat multikultural, masyarakat yang anggotanya memiliki latar belakang budaya (cultural background) beragam. Kemajemukan dan multikulturalitas mengisyaratkan adanya perbedaan. Bila dikelola secara benar, kemajemukan dan multikulturalitas menghasilkan energi hebat. Sebaliknya, bila tidak dikelola secara benar, kemajemukan dan multikulturalitas bisa menimbulkan bencana dahsyat. Pedoman kehidupan berbangsa dan bernegara yang sarat dengan itikad menjaga, melindungi, mempersatukan dan membangun bangsa untuk mampu meraih kemajuan adab, setara dengan bangsa-bangsa maju lainnya di dunia seolah-olah menjadi barang usang yang 
sudah ditinggalkan. Manifesto kultural Bhinneka Tunggal Ika yang merupakan tekad untuk membentuk kohesi sosial dan integrasi sosial, serta menyiratkan landasan mutualisme (kebersamaan, dalam perasaan maupun perilaku) dan kerjasama yang didasarkan atas kepentingan bersama dan perasaan kebersamaan, itu pun semakin pudar. Padahal makna dari manifesto kultural itu adalah ternanamnya perasaan saling memiliki dan menghargai sesama warganegara Indonesia, meski dengan latar belakang etnik dan kebudayaan yang berbeda-beda

\section{PEMBAHASAN}

\section{A. Pengertian persatuan dan kesatuan bangsa}

- Persatuan / Kesatuan: Persatuan/kesatuan berasal dari kata satu yang berarti utuh atau tidak terpecah-belah. Persatuan/kesatuan mengandung arti "bersatunya macam-macam corak yang beraneka ragam menjadi satu kebulatan yang utuh dan serasi."

- Indonesia: Mengandung dua pengertian, yaitu pengertian Indonesia ditinjau dari segi geografis dan dari segi bangsa.

Dari segi geografis, Indonesia berarti bagian bumi yang membentang dari $95^{\circ}$ sampai $141^{\circ}$ Bujur Timur dan $6^{\circ}$ Lintang Utara sampai 11 o Lintang Selatan atau wilayah yang terbentang dari Sabang sampai Merauke.

Indonesia dalam arti luas adalah seluruh rakyat yang merasa senasib dan sepenanggungan yang bermukim di dalam wilayah itu.

Persatuan dan kesatuan Bangsa Indonesia berarti persatuan bangsa yang mendiami wilayah Indonesia. Persatuan itu didorong untuk mencapai kehidupan yang bebas dalam wadah negara yang merdeka dan berdaulat.

\section{B. Makna dan pentingnya persatuan dan kesatuan bangsa}

Kesatuan bangsa Indonesia yang kita rasakan saat ini, itu terjadi dalam proses yang dinamis dan berlangsung lama, karena persatuan dan kesatuan bangsa terbentuk dari proses yang tumbuh dari unsur-unsur sosial budaya masyarakat Indonesia sendiri, yang ditempa dalam jangkauan waktu yang lama sekali.

Unsur-unsur sosial budaya itu antara lain seperti sifat kekeluargaan dan jiwa gotongroyong. Kedua unsur itu merupakan sifat-sifat pokok bangsa Indonesia yang dituntun oleh asas kemanusiaan dan kebudayaan. Karena masuknya kebudayaan dari luar, maka terjadi proses akulturasi (percampuran kebudayaan). Kebudayaan dari luar itu adalah kebudayaan Hindu, Islam, Kristen dan unsur-unsur kebudayaan lain yang beraneka ragam. Semua unsur-unsur kebudayaan dari luar yang masuk diseleksi oleh bangsa Indonesia. Kemudian sifat-sifat lain terlihat dalam setiap pengambilan keputusan yang menyangkut kehidupan bersama yang senantiasa dilakukan dengan jalan musyawarah dan mufakat. Hal itulah yang mendorong terwujudnya persatuan 
bangsa Indonesia. Jadi makna dan pentingnya persatuan dan kesatuan bangsa dapat mewujudkan sifat kekeluargaan, jiwa gotong-royong, musyawarah dan lain sebagainya.

Tahap-tahap pembinaan persatuan bangsa Indonesia itu yang paling menonjol ialah sebagai berikut:

1. Perasaan senasib.

2. Kebangkitan Nasional

3. Sumpah Pemuda

4. Proklamasi Kemerdekaan

\section{Cara Mewujudkan Persatuan Dan Kesatuan Bangsa}

Hal-hal yang berhubungan dengan arti dan makna persatuan Indonesia apabila dikaji lebih jauh, terdapat beberapa prinsip yang juga harus kita hayati serta kita pahami lalu kita amalkan.

Prinsip-prinsip itu adalah :

1. Prinsip Bhineka Tunggal Ika

Prinsip ini mengharuskan kita mengakui bahwa bangsa Indonesia merupakan bangsa yang terdiri dari berbagai suku, bahasa, agama dan adat kebiasaan yang majemuk. Hal ini mewajibkan kita bersatu sebagai bangsa Indonesia.

2. Prinsip Nasionalisme Indonesia

Kita mencintai bangsa kita, tidak berarti bahwa kita mengagung-agungkan bangsa kita sendiri. Nasionalisme Indonesia tidak berarti bahwa kita merasa lebih unggul daripada bangsa lain. Kita tidak ingin memaksakan kehendak kita kepada bangsa lain, sebab pandangan semacam ini hanya mencelakakan kita. Selain tidak realistis, sikap seperti itu juga bertentangan dengan sila Ketuhanan Yang Maha Esa dan Kemanusiaan yang adil dan beradab.

3. Prinsip Kebebasan yang Bertanggung jawab

Manusia Indonesia adalah makhluk ciptaan Tuhan Yang Maha Esa. Ia memiliki kebebasan dan tanggung jawab tertentu terhadap dirinya, terhadap sesamanya dan dalam hubungannya dengan Tuhan Yang maha Esa.

\section{Prinsip Wawasan Nusantara}

Dengan wawasan itu, kedudukan manusia Indonesia ditempatkan dalam kerangka kesatuan politik, sosial, budaya, ekonomi, serta pertahanan keamanan. Dengan wawasan itu manusia Indonesia merasa satu, senasib sepenanggungan, sebangsa dan setanah air, serta mempunyai satu tekad dalam mencapai cita-cita pembangunan nasional. 
5. Prinsip Persatuan Pembangunan untuk Mewujudkan Cita-cita Reformasi

Dengan semangat persatuan Indonesia kita harus dapat mengisi kemerdekaan serta melanjutkan pembangunan menuju masyarakat yang adil dan makmur

\section{Nilai-nilai dasar yang menjadi landasan terbentuknya toleransi antar umat beragama Islam dan Keristen di dusun Segaran kecamatan Dianggu kabupaten Mojokerto}

Masing-masing agama seharusnya berusaha keras untuk mengisi pemahaman dan kegiatannya dengan hal-hal yang mendorong hubungan saling bekerjasama untuk semua orang. Masyarakat Dusun Segaran mengedepankan sikap toleransi antar umat beragama yang dapat menerima kehadiran agama lain dengan segala kegiatannya. Bahkan untuk memberikan suasana yang baik, penerimaan itu diimbangi dengan terjadinya pergaulan antar umat beragama. Karena dengan mengembangkan sikap saling mengasihi maka akan menjadi anak-anak bapamu yang disurga.

Sebagaimana yang dituturkan oleh Bapak Sarji S.TH selaku Pendeta agama Kristen bahwa kasih sayang itu tidak hanya tercurahkan kepada Tuhan Yang Maha Esa, akan tetapi juga mangasihi terhadap sesama manusia, semua ciptaan Tuhan baik itu binatang, tumbuhan, tanah, air, batuan dan bahkan terhadap musuh harus mengasihi. Sementara kasih kepada musuh dengan cara mendoakan agar kembali kepada jalan yang lurus. Seperti yang terdapat pada surat Al Kafirun ayat 6 yang berbunyi «Lakum Diinukum Waliyaddin» yang artinya untukmulah agamamu, dan untukkulah agamaku. Kedua adalah nilai budaya yang lahir dari kebiasaan-kebiasaan yang dilakukan oleh sekelompok orang dan telah menjadi tradisi di lingkungan masyarakat tertentu.

Misalkan kebiasaan gotong-royong, guyub rukun yang turut mewarnai kehidupan manusia. Masyarakat Dusun Segaran tetap mempertahankan budaya gotongroyong dan guyub rukun sebagai wujud kebutuhan bersama dan sekaligus nilai yang membangun sikap kebersamaan di tengah-tengah perbedaan agama. Nilai budaya gotong-royong tidak memandang manusia berdasarkan agama, ras dan pangkat, melainkan memiliki kedudukan yang setara. Sebagai contoh dalam lingkup RT berarti mengembangkan sikap saling membantu dan menghormati tetangga yang satu dengan tetangga yang lain.

Apabila dalam segi agama berarti melakukan hubungan kerjasama yang tidak hanya dilakukan oleh intern umat beragama, melainkan juga dengan agama-agama yang ada di Indonesia yaitu Islam, Kristen Katolik, Protestan, Budha, Hindu dan Konghuchu serta tidak mengganggu kegiatan agama kelompok yang tidak sefaham atau tidak seagama. Begitu mendasarnya kebutuhan ini sehingga memaksa setiap orang, golongan atau kelompok untuk saling beradaptasi, berkomunikasi dan bergaul satu dengan yang lainnya. Untuk menuju persaudaraan yang sejati maka sikap saling mengejek, menghina harus dihindari. Berangkat dari mengerjakan sesuatu yang baik dan besar tidak mungkin sendirian kita butuh orang lain. 
Apabila terdapat tetangga yang membutuhkan pertolongan maka harus dibantu tanpa memandang orang itu kaya atau miskin. Hidup di dalam lingkungan masyarakat yang dibutuhkan adalah sikap tolongmenolong sehingga dapat mewujudkan lingkungan pergaulan hidup yang aman, damai dan sejahtera. Mengingat, bangsa Indonesia memiliki beragam agama dan budaya yang merupakan warisan nenek moyang. Sehingga perbedaan yang ada tidak dijadikan tonggak untuk saling menjatuhkan melainkan dijadikan sebagai aset untuk bersatu, bersama-sama mengisi dan melanjutkan perjuangan bangsa melalui kesuksesan pembangunan desa.

Tetangga yang sakit harus dijenguk tanpa memandang latar agama. Yang menjadi musuh dalam era saat ini adalah kemiskinan dan kebodohan yang terus merongrong kehidupan bangsa. Untuk mengantisipasi masalah yang lebih besar maka harus memiliki satu tekad, satu tujuan dan satu harapan membentuk bangsa Indonesia yang satu. Pada dasarnya sejak dahulu masyarakat Dusun Segaran sudah saling menghormati dan menghargai satu sama yang lain.

Berlandaskan warisan nenek moyang dari Mbah Samodin Simson, masyarakat Dusun Segaran sudah memiliki sikap toleran terhadap perbedaan agama yang ada. Kabupaten Mojokerto tidak pernah terjadi konflik yang disebabkan perbedaan agama, melainkan hanya permasalahan kecil. Perbedaan pandangan dalam suatu hubungan kemasyarakatan merupakan hal yang wajar. Hal ini didasarkan pada pemikiran agama yang terbuka dan selalu mengutamakan kerukunan hidup. Berusaha memiliki pemikiran dan pemahaman yang terbuka akan esensi hidup.

Karena yang namanya saudara tidak mungkin saling menyakiti, mengejek ataupun saling curiga. Dapat dilihat dari upaya yang dilakukan oleh Kepala Dusun Segaran dan para tokoh agama dalam mengajarkan sikap toleransi. Sebagai pemimpin harus dapat memberikan contoh, baik itu ucapan dan perilaku yang mencerminkan sikap saling menghormati dan menghargai perbedaan agama. Salah satu cara yang ditempuh oleh Kepala Dusun Segaran agar masyarakat tetap mengembangkan sikap toleransi antar umat beragama yaitu melalui sambutan-sambutan pada saat event rapat RT, PKK, dalam rangka perayaan seperti natal dan halal binhalal. Hidup berdampingan di lingkungan masyarakat yang heterogen dibutuhkan kesabaran. Sikap sabar diwujudkan dengan tidak mengejek ataupun menghina umat yang tidak beragama, melainkan memberikan waktu dan tempat kepada orang yang tidak seagama untuk beribadah sesuai dengan kepercayaannya masing-masing.

\section{PENUTUP}

Segala sesuatu yang kita nikmati keberadaannya kita terima begitu saja tanpa membayangkan betapa sulitnya meraih, antara lain bahasa Indonesia sebagai bahasa persatuan, kemerdekaan, dan pembangunan-pembangunan yang kita nikmati saat ini. Masalah persatuan dan kesatuan bangsa bukan hanya diperlukan pada saat bangsa Indonesia menghadapi kekuasaan asing saja, melainkan terus diperlukan hingga sekarang, agar kemerdekaan bangsa dan negara yang berhasil dicapai oleh para 
pendahulu kita tidak digoyah dan hancur di tangan kita. Kalau sekarang nilai-nilai itu sepertinya terabaikan dalam berbangsa, itu adalah kesalahan transformasi nilai. Maka, yang kita butuhkan di masa depan adalah sejarah sebagai pembelajaran moral untuk kepentingan kebangsaan. Masa lalu sebagai pengalaman adalah guru dan darinya kita dapat berefleksi dan memperoleh banyak nilai yang terkandung di dalamnya. Berdasarkan pembahasan maka dapat disimpulkan bahwa nilai nilai dasar yang menjadi landasan terbentuknya toleransi antar umat beragama Islam dan Kristen di Dusun Segaran Kecamatan Dlanggu Kabupaten Mojokerto secara normatif terdapat pada nilai agama dan nilai budaya. Bentuk toleransi antar umat beragama Islam dan Kristen di Dusun Segaran Kecamatan Dlanggu Kabupaten Mojokerto dapat ditinjau secara toleransi agama dan toleransi sosial.

\section{DAFTAR PUSTAKA}

Nisvilyah, L. (2013). Toleransi antarumat beragama dalam memperkokoh persatuan dan kesatuan bangsa (studi kasus umat Islam dan Kristen Dusun Segaran Kecamatan Dlanggu Kabupaten Mojokerto). Kajian Moral dan Kewarganegaraan, 2(1), 382-396.

Kartodirdjo, Sartono,Multidimensi Pembangunan Bangsa: Etos Nasionalisme dan Negara Kesatuan, Yogyakarta, Kanisius, 1999.

Ade Makmur Kartawinata. 1999. Persatuan dan Kesatuan Bangsa: Suatu renungan Pembentukan Indonesia Merdeka Ke Arah Kebudayaan Kebangsaan . Bandung: Primaco Akademika. 